\title{
Distinct requirements for TrkB and TrkC signaling in target innervation by sensory neurons
}

\author{
Antonio Postigo, ${ }^{1,9,10}$ Anna Maria Calella, ${ }^{2,9}$ Bernd Fritzsch, ${ }^{3,9}$ Marlies Knipper, ${ }^{4,9}$ David Katz, ${ }^{5}$ \\ Andreas Eilers, ${ }^{7}$ Thomas Schimmang, ${ }^{6}$ Gary R. Lewin, ${ }^{7}$ Rüdiger Klein, ${ }^{1,8,11}$ and Liliana Minichiello ${ }^{1,2,11}$ \\ ${ }^{1}$ European Molecular Biology Laboratory, D-69117 Heidelberg, Germany; ${ }^{2}$ European Molecular Biology Laboratory, 00016 \\ Monterotondo, Italy; ${ }^{3}$ Department of Biomedical Sciences, Creighton University, Omaha, Nebraska 68178, USA; ${ }^{4}$ Hearing \\ Research Center Tübingen, Molecular Neurobiology, D-72076 Tübingen, Germany; ${ }^{5}$ Department of Neurosciences, Case \\ Western Reserve University School of Medicine, Cleveland, Ohio 44106-4975, USA; ${ }^{6}$ University of Hamburg, Zentrum für \\ Molekulare Neurobiologie, 20251 Hamburg, Germany; ${ }^{7}$ Growth Factors and Regeneration Group, Department of \\ Neuroscience, Max-Delbrück Center for Molecular Medicine, D-13092 Berlin, Germany; ${ }^{8}$ Max-Planck Institute of \\ Neurobiology, D-82152 Martinsried, Germany
}

Signaling by brain-derived neurotrophic factor (BDNF) via the TrkB receptor, or by neurotrophin-3 (NT3) through the TrkC receptor support distinct populations of sensory neurons. The intracellular signaling pathways activated by Trk (tyrosine kinase) receptors, which in vivo promote neuronal survival and target innervation, are not well understood. Using mice with TrkB or TrkC receptors lacking the docking site for She adaptors (trkB $B^{\text {shc/shc }}$ and $\operatorname{trk} C^{\text {shc/shc }}$ mice), we show that TrkB and TrkC promote survival of sensory neurons mainly through She site-independent pathways, suggesting that these receptors use similar pathways to prevent apoptosis. In contrast, the regulation of target innervation appears different: in $t r k B^{\text {shc/shc }}$ mice neurons lose target innervation, whereas in $t r k C^{s h c / s h c}$ mice the surviving TrkC-dependent neurons maintain target innervation and function. Biochemical analysis indicates that phosphorylation at the She site positively regulates autophosphorylation of TrkB, but not of TrkC. Our findings show that although TrkB and TrkC signals mediating survival are largely similar, TrkB and TrkC signals required for maintenance of target innervation in vivo are regulated by distinct mechanisms.

[Key Words: Trk receptors; Shc site; distinct signaling requirements; target innervation]

Received October 2, 2001; revised version accepted January 10, 2002.

The neurotrophins are a family of polypeptide growth factors that use specific receptor tyrosine kinases (the Trk family) to exert their diverse functions in the developing and the mature nervous system (Bibel and Barde 2000). Specifically, nerve growth factor (NGF) is the preferred ligand for TrkA; brain-derived neurotrophic factor (BDNF) and neurotrophin-4 (NT-4) both bind TrkB; and neurotrophin-3 (NT3) shows high affinity for TrkC, although it is also able to signal through TrkA and TrkB (Davies et al. 1995; Kaplan and Miller 1997). Studies of mice carrying gene deletions of either neurotrophins or Trk receptors have shown that the neurotrophin/Trk signaling system is required for the survival of different populations of peripheral neurons during development, including sensory neurons of the cochlear and vestibular

\footnotetext{
${ }^{9}$ These authors contributed equally to this work.

${ }^{10}$ Present address: Imperial Cancer Research Fund, 44 Lincolns Inn Fields, London WC2A 3PX, UK.

${ }^{11}$ Corresponding authors.

E-MAIL rklein@neuro.mpg.de; FAX 49-89-8578-3152.

E-MAIL mini@EMBL-Monterotondo.it; FAX 39-06-90091-272.

Article and publication are at http://www.genesdev.org/cgi/doi/10.1101/ $\operatorname{gad} .217902$.
}

ganglion (Fritzsch et al. 1997; Bibel and Barde 2000). In the central nervous system, neurotrophins support survival and differentiation of selected neuron populations in a partially redundant manner (Minichiello and Klein 1996; Alcantara et al. 1997). Finally, in the mature nervous system, neurotrophins can modulate both shortterm and long-term synaptic transmission. In particular, in bdnf null mutant and $\operatorname{trk} B$ conditional mutant mice, long-term potentiation in the CA3-CA1 hippocampal region is impaired (Korte et al. 1995; Patterson et al. 1996; Minichiello et al. 1999; Xu et al. 2000).

It is well established that Trk receptors are structurally similar, and that their ligand-induced dimerization gives rise to autophosphorylation of specific tyrosines in the activation loop of their kinase domains. Subsequent trans-phosphorylation of tyrosines in the juxtamembrane and C-terminal regions induces binding of different adaptor proteins that activate well-known signaling cascades like the Ras/MAPK pathway and the phosphoinositide 3 kinase (PI3K/AKT) pathway. The association of phospholipase-C $\gamma$ (PLC $\gamma$ ) with Trk regulates intracellular $\mathrm{Ca}^{2+}$ levels, although the significance of this path- 
way for neurotrophin biology remains to be defined (Bibel and Barde 2000). Signaling studies have mostly been performed on TrkA and TrkB in either immortalized PC12 cells or primary sympathetic neurons in culture (Kaplan and Miller 2000). Despite significant progress in this area, it remains to be established whether activation of different Trk receptors leads to similar or different biological outcomes in vivo. There are examples suggesting that the activation of different Trk receptors leads to different biological results. Activation of TrkA in sympathetic neurons by NGF or NT3 differentially regulates survival and neuritogenesis (Berglund and Ryugo 1986). Adenovirally expressed TrkB uses both PI3K and Mek to regulate sympathetic neuron survival in vitro, whereas endogenous TrkA uses PI3K exclusively (Atwal et al. 2000). BDNF and NT3 have opposing roles in regulating the growth of basal dendrites of pyramidal neurons in the developing neocortex. This observation suggests interesting differences in signaling capabilities of TrkB and TrkC receptors, although the molecular nature of these differences is unknown (Shieh and Ghosh 1997; McAllister et al. 1999). To compare signaling through two Trk receptors in vivo, we generated mice with a germ-line mutation in the Shc site in the juxtamembrane region of the TrkC receptor (trk $C^{s h c / s h c}$ mice), and compared these with mice with a similar point mutation in the TrkB receptor (trkB $B^{s h c / s h c}$ mice; Minichiello et al. 1998). We have focused our analysis on a well-described and experimentally accessible biological system, namely, the peripheral ganglia of the inner ear.

Sensory neurons of the cochlear and vestibular ganglia are bipolar, with a peripheral process (afferent) contacting the hair cells in their respective sensory epithelia, and a central process that projects to the cochlear and vestibular nuclei of the medulla (Spoendlin 1988). The afferent fibers from the cochlear sensory neurons innervate the cochlear sensory epithelium, or Organ of Corti, whereas the afferent fibers from the vestibular neurons innervate three different sensory epithelia, the saccular and utricular maculae and the ampullary crista of the semicircular canals. Efferent fibers from neurons located in the brainstem also contact all these sensory epithelia. Based on in vivo analysis of mice carrying null mutations for the Trk receptors or their cognate neurotrophin ligands, it has been established that cochlear neurons mainly depend on NT3/TrkC for their survival, whereas vestibular neurons mainly depend on BDNF/TrkB (for review, see Fritzsch et al. 2000). TrkB and TrkC signals are also required to maintain other sensory neuron subpopulations. Nodose-petrosal sensory neurons, which innervate visceral targets, depend on TrkB for their survival (Conover et al. 1995). A small proportion (18\%) of dorsal root ganglia (DRG) neurons innervate muscle spindles and convey proprioceptive information to the spinal cord. Studies from null mutant mice show that this DRG subpopulation critically depends on NT3/ TrkC interaction for survival (Ernfors et al. 1994; Klein et al. 1994). DRGs also contain many subclasses of mechanoreceptive neurons, which all have distinct electrophysiological properties. Among these, the slowly adapting (SA) and D-hair mechanoreceptive neurons depend on TrkC and NT3 for their survival (Airaksinen et al. 1996).

Our comparative analysis of $t r k B^{s h c / s h c}$ and $t r k C^{s h c / s h c}$ mice revealed distinct requirements for the Shc site in TrkB and TrkC signaling in sensory neurons in vivo. In both mutants, the majority of inner ear sensory neurons survived, indicating that both receptors promoted longterm survival of sensory neurons in a Shc site-independent manner. In contrast, target innervation of sensory neurons was lost in $t r k B^{s h c / s h c}$ mice, whereas target innervation and neuronal function were maintained in trk $C^{\text {shc/shc }}$ mice. These results suggest that TrkB receptor signals that maintain target innervation require the Shc site, whereas TrkC receptors use Shc site-independent mechanisms to maintain target innervation. We provide biochemical evidence that may explain the phenotypic differences between TrkB and TrkC revealed by mutation of the Shc binding site.

\section{Results}

\section{Mutation of the Shc-binding site in TrkC}

We introduced a mutation of the Shc adaptor binding site (Y516F) of the TrkC receptor into the mouse germ line as outlined in Figure 1. Homozygous mutant $\operatorname{trk} C^{s h c / s h c}$ mice showed the same lack of proprioception as mice homozygous for the trk $C^{T K}$ allele, in which the tyrosine kinase coding region was targeted (Klein et al. 1994). The reason for this severe phenotype was that the $\operatorname{trk} C^{s h c}$ allele did not express TrkC protein (data not shown). After the neo gene was removed by crossing with a deleter-Cre strain (Schwenk et al. 1995), TrkC expression was completely rescued (Fig. 1C), and homozygous mutants no longer showed a lack of proprioception (data not shown). All subsequent analysis was done using $\operatorname{trk} C^{s h c}$; $n e \mathrm{O}^{-}$; $c r e^{-}$mutants, whereas the $\operatorname{trk} B^{\text {shc/shc }}$ mutants still retained the neo cassette, which did not interfere with TrkB expression as reported in Minichiello et al. (1998).

\section{Signaling by mutant TrkC receptors in primary neurons}

To investigate the signaling properties of mutant TrkC receptors, we made use of a mutant version of NT3 (here referred to as $\mathrm{NT}^{\star}{ }^{\star}$ ), which preferentially interacts with TrkC, but not with the related TrkB or TrkA receptors (Rydén and Ibañez 1996). To determine receptor specificity, we used NIH3T3 cell lines stably expressing TrkB or TrkC and stimulated with either wild-type NT3 or $\mathrm{NT}^{\star}{ }^{\star}$. Stimulation with $20 \mathrm{ng} / \mathrm{mL} \mathrm{NT3}^{\star}$ failed to activate $\operatorname{TrkB}$, whereas its effects on TrkC were similar to those of wild-type NT3 (Fig. 2A). To avoid activating TrkB, we stimulated primary cortical neurons derived from $\mathrm{trk} C^{\text {shc/shc }}$ mice with $20 \mathrm{ng} / \mathrm{mL} \mathrm{NT3}{ }^{\star}$. As expected, tyrosine phosphorylation of Shc adaptor proteins was not significantly induced after NT3* ${ }^{\star}$ stimulation (Fig. 2B). FGF receptor substrate-2 (FRS2), which also 


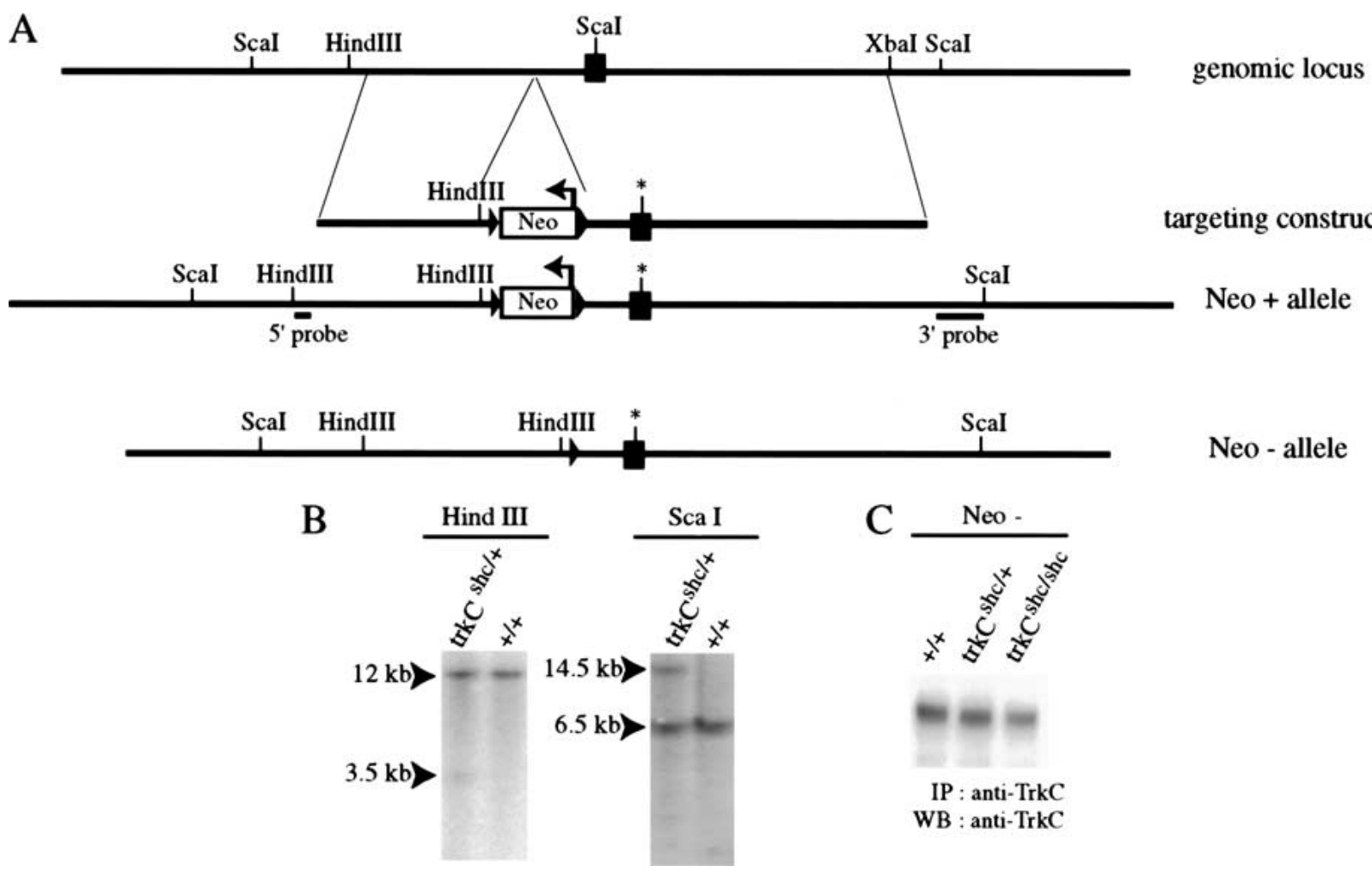

Figure 1. Introduction of the $\operatorname{trk} C^{s h c}$ allele into the mouse germ line. $(A)$ Schematic diagram of the targeted $t r k C^{s h c}$ allele. The black box represents the juxtamembrane exon of the mouse trkC gene; the asterisk indicates the mutated Shc-binding site (NPQF $\left.{ }^{\star}\right)$. The PGK-Neo is indicated as an open box cassette (arrow indicates transcriptional orientation) and is flanked by LoxP sites (arrowheads). The $\mathrm{Y} \rightarrow$ F mutation destroys the ScaI site in the mutant allele. (B) Southern blotting analysis was carried out using probes located 5' and $3^{\prime}$ outside the genomic sequence included in the targeting construct to detect the correct targeting event. $(C)$ Removal of the neo gene from the $t r k C^{s h c}$ mutant allele rescues TrkC expression. Wild-type and mutant TrkC receptors were immunoprecipitated with anti-TrkC antibody and revealed by Western blotting with anti-TrkC antibody.

binds to the juxtamembrane Shc site of Trk receptors (Meakin et al. 1999), was efficiently tyrosine-phosphorylated in wild-type neurons, but not in $\operatorname{trk} C^{\text {shc/shc }}$ or in $\operatorname{trk} B^{s h c / s h c}$ neurons, stimulated with NT3* or BDNF, respectively (Fig. 2C). In contrast, binding of the C-terminal SH2 domain of PLC $\gamma$ to the phosphorylated C-terminal tyrosine residue in TrkC was unaffected by the Shc site mutation (Fig. 2D).

We next investigated the effects of the Shc site mutation on downstream targets. Trk receptors are known to activate the Ras/MAPK pathway, to a large extent by recruiting the Grb2/SOS complex to the Shc site (Bibel and Barde 2000). We had previously observed that phosphorylation of ERK/MAPKs was not efficiently induced or sustained in BDNF-stimulated neurons derived from trk $B^{\text {shc/shc }}$ mutants (Fig. 2F; Minichiello et al. 1998). The same was seen when cortical neurons from $t r k C^{s h c / s h c}$ mice were stimulated with NT3* (Fig. 2E). The Shc site also controls the activation of the PI3K/AKT pathway by recruitment of the multisite adaptor Gab1 to receptorbound Shc and FRS2 proteins (Bibel and Barde 2000). Phosphorylation of AKT was not efficiently induced or sustained in TrkC and TrkB mutant receptors stimulated with $\mathrm{NT}^{\star}{ }^{\star}$ and BDNF, respectively (Fig. 2E,F). Thus, mutation of the Shc adaptor binding site in the
TrkB and TrkC receptors has very similar effects at least on two downstream signaling pathways in primary neurons.

Comparable loss of sensory neurons in $\mathrm{trkC}^{\mathrm{shc} / \mathrm{shc}}$ and trkB $\mathrm{B}^{\text {shc/she }}$ mutants

We had previously reported that loss of the Shc-binding site in TrkB resulted in a modest $(25 \%)$ reduction of TrkB-dependent vestibular neurons compared with control littermates at postnatal day 7 (P7; Fig. 3C; Minichiello et al. 1998). The remaining $75 \%$ of vestibular neurons survived to adulthood (Fig. 3C), suggesting that pathways independent of the Shc site mediate the survival response of most vestibular neurons to BDNF. To compare the effects of the Shc site mutations in TrkB and TrkC receptors, we investigated the survival of TrkC-dependent sensory neurons. We observed a similar modest $(25 \%)$ reduction of cochlear neurons in trk $C^{\text {shc/shc }}$ mice compared with control littermates at P7. No further cell loss was found at P70 (Fig. 3A). This suggests that the requirements of Trk receptor signaling for survival of sensory neurons are rather similar. Because inner ear sensory neurons coexpress TrkB and TrkC receptors (Mou et al. 1997; Fariñas et al. 2001), we 
Postigo et al.
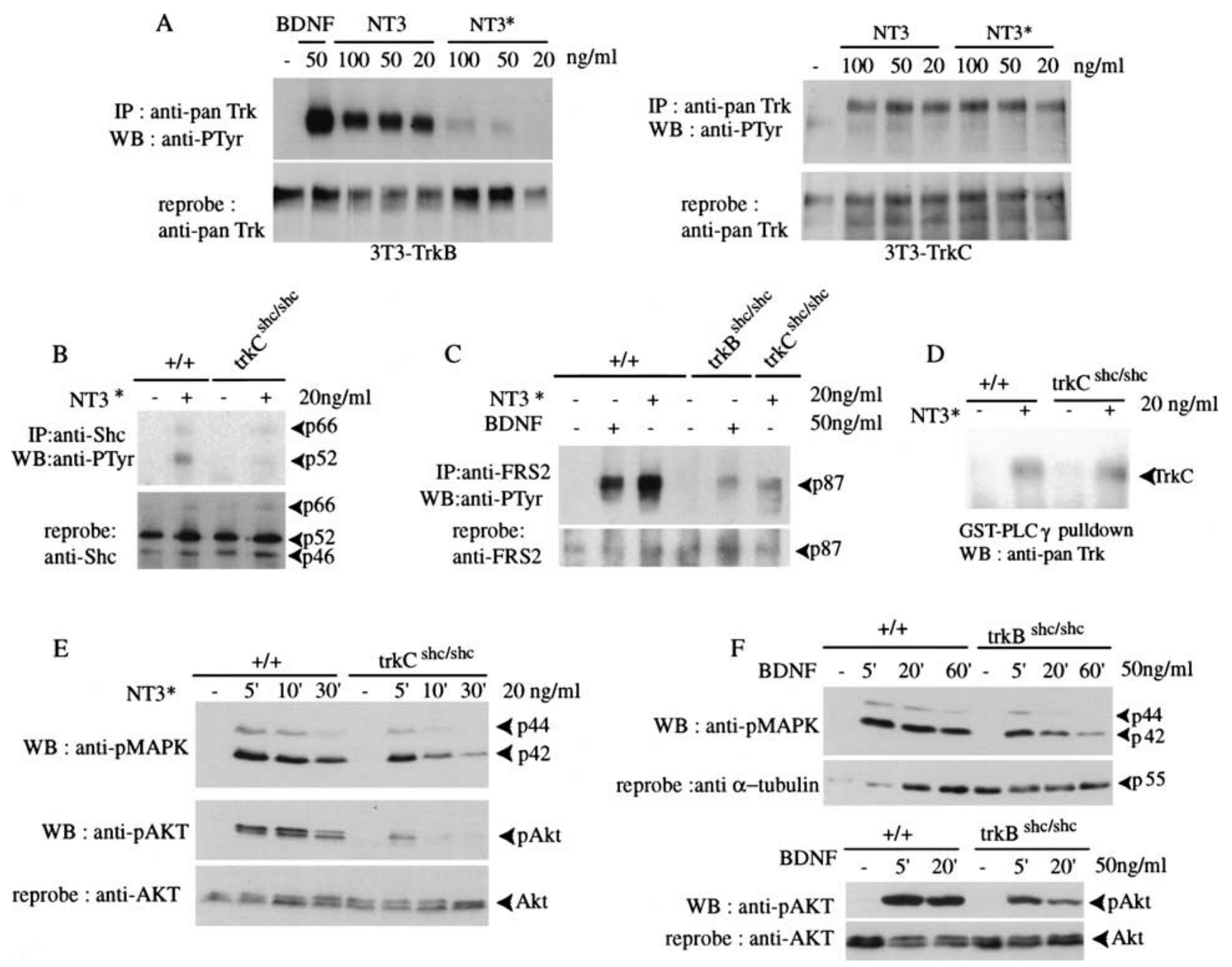

Figure 2. Signaling by mutant $\operatorname{TrkC}^{\text {shc }}$ receptors in primary cortical neurons. $(A)$ A mutant version of NT3 $\left(\mathrm{NT}^{\star}\right)$ preferably interacts with TrkC and only poorly with TrkB. NIH-3T3 cell lines stably expressing TrkB or TrkC were stimulated with either wild-type NT3 or NT3*. Cell lysates were immunoprecipitated with anti-panTrk antibody and autophosphorylated receptors were detected with anti-PTyr antibody. At $20 \mathrm{ng} / \mathrm{mL}$, NT3* failed to activate TrkB, whereas wild-type NT3 efficiently induced autophosphorylation of TrkB receptors. Blots were reprobed with anti-panTrk antibody to control for total Trk protein. (B) Tyrosine phosphorylation of Shc proteins. Cortical neurons were stimulated with NT3* for $5 \mathrm{~min}$. Cell lysates were immunoprecipitated with anti-Shc antibody followed by immunoblotting with anti-PTyr antibody. The blot was reprobed with anti-Shc antibody. (C) Lack of efficient FRS2 binding to mutant TrkC ${ }^{\text {shc }}$ receptors. Cortical neurons derived from wild-type, $\operatorname{trk} B^{s h c / s h c}$ and $t r k C^{s h c / s h c}$ embryos were stimulated with either BDNF or NT3* as indicated. Cell lysates were incubated with anti-FRS2 antibody followed by immunoblotting with anti-PTyr antibody. (D) PLC $\gamma$ binding to mutant TrkC ${ }^{\text {shc }}$ receptors. Wild-type and mutant cortical neurons were stimulated with NT3*. Cell lysates were incubated with the C-terminal SH2 domain of PLC $\gamma$ (GST-PLC $\gamma$ ) coupled to glutathione sepharose. Bound proteins were immunoblotted with anti-panTrk antibody. Note efficient binding of activated TrkC ${ }^{\text {shc }}$ to PLC $\gamma 1$ in $t r k C^{\text {shc/shc }}$ mutant neurons. $(E, F)$ Reduced and short-lived ERK/MAPK and AKT phosphorylation in either trk $C^{\text {shc/shc }}$ or trk $B^{\text {shc/shc }}$ cortical neurons. Cell lysates from wild-type and specific mutant cortical neurons after stimulation were subjected to SDS-PAGE followed by immunoblotting with antibody against the phosphorylated forms of p42/p44 ERKs. The blot was reprobed with anti-phospho-AKT antibody and a second time with antibody against unphosphorylated AKT to control for the amount of protein loaded.

generated double-mutant $\operatorname{trk} B^{s h c / s h c} ; \operatorname{trk} C^{s h c / s h c}$ mice to investigate whether or not Trk signaling via the Shc site was partially redundant. Indeed, whereas cochlear neuronal loss in P70 single-mutant $t r k B^{\text {shc/shc }}$ mice was marginal $(13 \%)$, the reduction in neuron number in double mutants was higher $(56 \%)$ than would be expected $(38 \%)$ if the effects were additive (Fig. 3B). In summary, these results indicate a very similar and partially redundant role (when the two receptors are coexpressed) for the Shc site in TrkB and TrkC receptor-mediated survival of sensory neurons.

Loss of target innervation of trk $\mathrm{B}^{\text {shc/shc }}$ vestibular neurons

We noticed that cell body sizes of vestibular neurons were modestly reduced in $t r k B^{s h c / s h c}$ mutants compared with controls (Table 1). At P7, vestibular neuron somas 
A

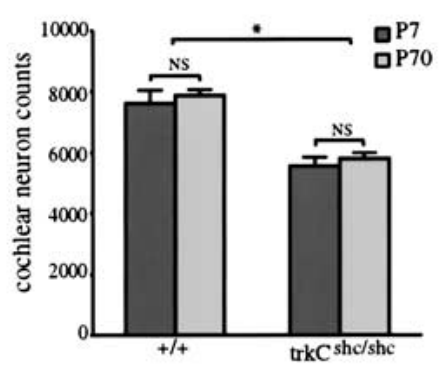

B

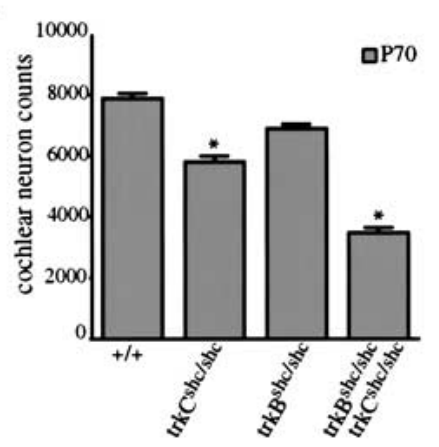

C

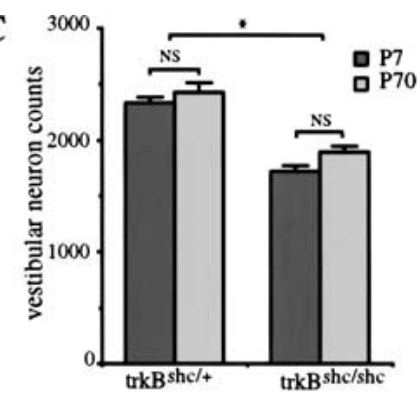

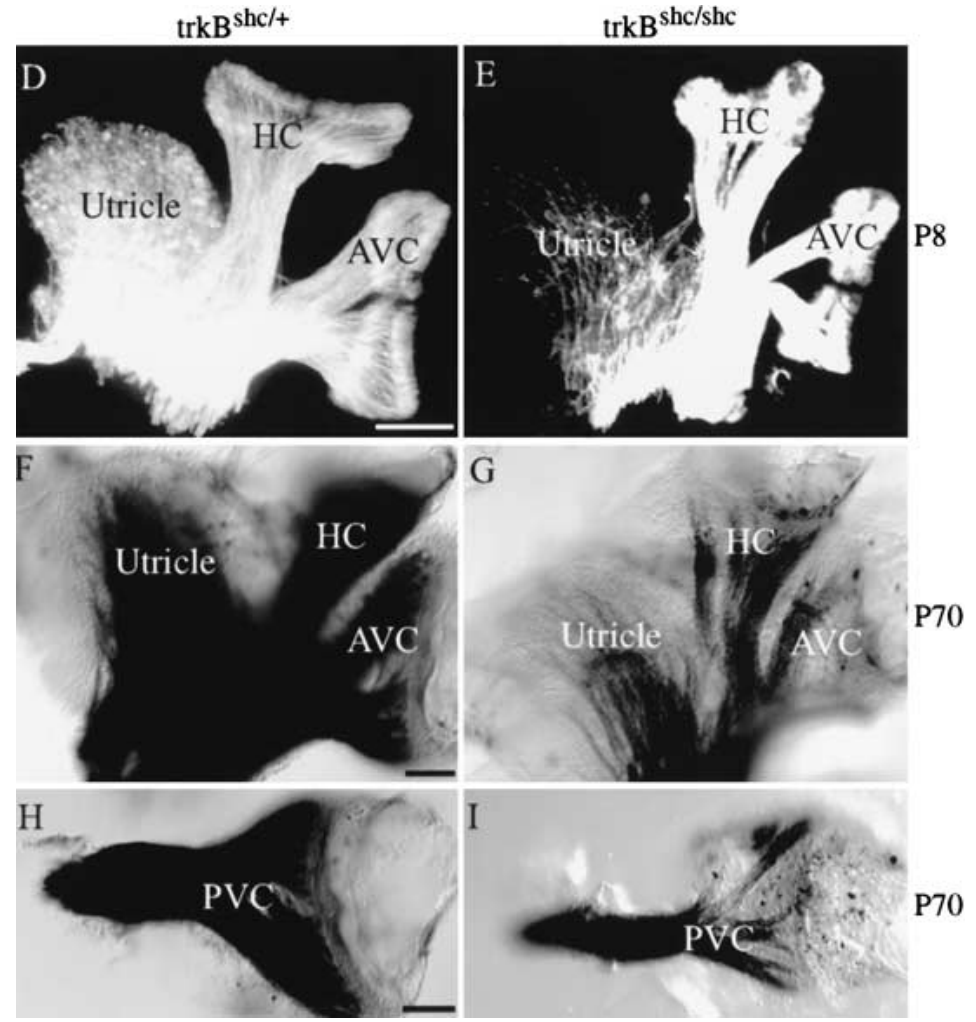

Figure 3. Role of $\operatorname{TrkB}^{\text {shc }}$ and $\operatorname{TrkC}^{\text {shc }}$ in survival and target innervation. $(A-C)$ Graphs depicting numbers of cochlear neurons per ganglion in various mutants mice. (A) There was an $\sim 25 \%$ loss of cochlear neurons in P7 trk $C^{\text {shc/shc }}$ mutants compared with wild-type littermates ( $n=3-4$ ganglia/genotype; $P=0.0001, t$-test). No further loss was observed in adult (P70) mutant mice $(P=0.43, t$-test $)$. (B) Double-mutant $\operatorname{trk} B^{\text {shc/shc }}$; trk $C^{\text {shc/shc }}$ mice show more than additive effects in cochlear neuron loss. Whereas the loss of cochlear neurons in $\operatorname{trk} B^{\text {shc/shc }}$ mice was very modest $(13 \% ; n=4$ ganglia; $P=0.0036$, $t$-test), $56 \%$ of cochlear neurons disappeared in doublemutant $\operatorname{trk} B^{s h c / s h c}$; $t r k C^{s h c / s h c}$ mice at $\mathrm{P} 70(n=4$ ganglia; $P=0.0001$, $t$-test $).(C)$ There was an $\sim 25 \%$ loss of vestibular neuron in $\mathrm{P} 7 \mathrm{trk} B^{\mathrm{shc} / \mathrm{shc}}$ mutants compared with trk $B^{s h c /+}$ control littermates (no significant difference was observed in vestibular neuron survival between wild-type and $t r k B^{s h c /+}$ control mice; data not shown). No further loss was observed in adult (P70) mutant mice $(P=0.8$, $t$-test; $n=3-4$ animals, $n=6-8$ ganglia/genotype and time point). $(D, E)$ DiI tracing and $(F-I)$ osmium tetroxide myelin staining of the vestibular organ at P8 $(D, E)$ and $\mathrm{P} 70(F-I)$. Note the severe reduction of innervation of the utricle already at P8 in $\operatorname{trk} B^{\text {shc/shc }}$ mutants compared with heterozygotes. Also note the strong reduction of innervation of the vestibular canals at P70. (AVC) Anterior vertical canal; (HC) horizontal canal; (PVC) posterior vertical canal. Scale bar, $100 \mu \mathrm{m}(D-I)$. were $21 \%$ smaller compared with control mice, and at P70, soma sizes were further reduced $(27 \%)$. In contrast, cell body size of cochlear neurons was the same in trk $C^{s h c / s h c}$ mutants as in wild-type mice (Table 1). There was no reduction in cell body size of cochlear neurons even in $\operatorname{trk} B^{s h c / s h c}$; $\operatorname{trk} C^{\text {shc/shc }}$ mice. Given that neuronal atrophy could be the result of insufficient neurotrophic support, we investigated the innervation of sensory epithelia in $\operatorname{trk} B^{\text {shc/shc }}$ mutants. Afferent innervation of vestibular epithelia in newborn $t r k B^{s h c / s h c}$ mutants, as revealed by anti-neurofilament (NF200) immunofluorescence (Berglund and Ryugo 1986), was largely unaffected, whereas in adult mice anti-neurofilament staining was strongly reduced in all vestibular sensory epithelia of $\operatorname{trk} B^{\text {shc/shc }}$ mutants (data not shown). This indicated that the surviving $75 \%$ of vestibular neurons failed to maintain target innervation. Similar loss of target innervation was observed for adult efferent fibers using anti-synap- tophysin antibody (Wiechers et al. 1999; data not shown).

To obtain a more complete understanding of the vestibular organ, we used DiI tracing of dissected inner ears to visualize nerve fibers. At P0 we were unable to distinguish $t r k B^{s h c / s h c}$ mutants from controls. Specifically, we found numerous afferent and efferent fibers running to all vestibular sensory epithelia as well as the cochlea, in an apparently normal fashion (data not shown). At P8, however, the mutants showed a diminished density of fibers to all canal end organs, as well as the utricle (Fig. $3 \mathrm{D}, \mathrm{E})$. This reduction was more pronounced at P70 as shown by whole-mount osmium tetroxide myelin staining (Fig. 3F-I).

We quantified target innervation by measuring the diameter of the posterior vertical crista (PVC) nerve, which represents the only branch of the statoacoustic nerve that projects over a long distance to a canal sensory epi- 
Postigo et al.

Table 1. Cell body size of vestibular and cochlear neurons

\begin{tabular}{|c|c|c|c|}
\hline & Genotype & Mean $\pm \operatorname{SD}\left(\mu \mathrm{m}^{2}\right)$ & \\
\hline Vestibular (P7) & $\begin{array}{l}+/+ \\
\operatorname{trk} B^{S h c / S h c}\end{array}$ & $\begin{array}{l}53.6 \pm 2.3 \\
42.7 \pm 1.3^{\mathrm{a}}\end{array}$ & $\begin{array}{l}(n=93 / 2) \\
(n=76 / 2)\end{array}$ \\
\hline Vestibular (P70) & $\begin{array}{l}+/+ \\
\operatorname{trk} B \text { Shc/Shc }\end{array}$ & $\begin{array}{l}48.5 \pm 0.425 \\
35.3 \pm 2.7^{b}\end{array}$ & $\begin{array}{l}(n=253 / 2) \\
(n=248 / 2)\end{array}$ \\
\hline Cochlear (P70) & $\begin{array}{l}+/+ \\
\operatorname{trk} C^{S h c / S h c} \\
\operatorname{trk} B^{S h c / S h c} \\
\operatorname{trk} B^{S h c / S h c} \\
\operatorname{trk} C^{S h c / S h c}\end{array}$ & $\begin{array}{l}26.08 \pm 1.6 \\
25.59 \pm 1.8^{\mathrm{ns}} \\
27.02 \pm 0.74^{\mathrm{ns}} \\
25.30 \pm 2.36^{\mathrm{ns}}\end{array}$ & 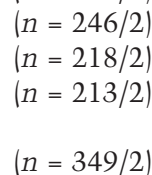 \\
\hline
\end{tabular}

Paraffin sections $(8 \mu \mathrm{m})$ derived from mutant and wild-type littermates were Nissl-stained with $0.1 \%$ cresyl violet. The area of different cell bodies of cochlear and vestibular organ was measured every five sections by using NIH Image Program. The mean values are expressed in $\mu \mathrm{m}^{2} \pm \mathrm{SD}$ (standard deviation). Statistical analysis was carried out using Student's $t$-test $\mid n=$ profiles/mice).

${ }^{\mathrm{a}} P<0.01$.

${ }^{\mathrm{b}} P<0.006$

ns, not significant.

thelium. Our data showed a severe and apparently progressive reduction in the diameter and area of this nerve in $t r k B^{s h c / s h c}$ mutants compared with control littermates (Fig. 4A-E). At P0, the mutant nerve already appears to be reduced and progressively falls behind control littermates at later ages. The fiber profile obtained for trk $B^{\text {shc/shc }}$ mutants at the light microscopic level clearly suggested a reduction in the number of myelinated fibers extending to the PVC as early as P0 and reaching $30 \%$ $40 \%$ at P26-P70 (Fig. 4F). Transmission Electron Microscopy of the mutant PVC nerve fibers revealed a reduction of the size of individual fibers at P26 and P70 (data not shown). Therefore, it is the combined effect of a reduction in fiber size and a loss of fibers that caused the reduction in PVC nerve diameter in $\operatorname{trk} B^{\text {shc/shc }}$ mutants.

\section{Intact target innervation of the remaining cochlear neurons in trkC $\mathrm{C}^{\text {shc/shc }}$ mutants}

We next asked if the Shc site had a similar role in TrkCdependent neurons. Therefore, we stained afferent and efferent sensory fibers innervating the organ of Corti in trkC $C^{\text {shc/shc }}$ mutants. Anti-NF200 immunostaining, which specifically stains afferent innervation, revealed normal fiber density in adult $t r k C^{s h c / s h c}$ mutants compared with trk $C^{s h c /+}$ littermates (Fig. 5A,B). Furthermore, no significant differences were noted in synaptophysin-immunopositive efferent fibers projecting to $\mathrm{OHC}$ and IHCs (Fig. 5C,D). Osmium tetroxide myelin staining of P23-P70 control and $t r k C^{s h c / s h c}$ mutant mice revealed that radial fibers and their innervation of hair cells is maintained in the mutants apart from the basal and the apical regions (data not shown). Even in doublemutant $\operatorname{trk} B^{\text {shc/shc }}$; trk $C^{\text {shc/shc }}$ mice, the remaining $44 \%$ of cochlear neurons maintained target innervation (data not shown). To test if cochlear innervation in $\mathrm{trk} C^{\text {shc/shc }}$ mutants was functional, we determined frequency-de- pendent brainstem responses in adult $\operatorname{trk}^{\mathrm{shc/+}}$ and trk $C^{\text {shc/shc }}$ mutant mice, respectively. No significant differences were noted between $\operatorname{trk} C^{\text {shc/+ }}$ and $\operatorname{trk} C^{\text {shc/shc }}$ mice (data not shown). Accordingly, hearing thresholds, determined from click-evoked brain stem responses in 2-month-old $t r k C^{\text {shc/+ }}$ mice, showed thresholds of $26.5 \pm 4.2 \mathrm{~dB}$ SPL $( \pm \mathrm{SD}, n=5)$, not significantly different from those is $\operatorname{trk} C^{\text {shc/shc }}$ mice with $24.6 \pm 5.5 \mathrm{~dB}$ SPL $\left({ }_{ \pm} \mathrm{SD}, n=6 ; p>0.592\right)$. These results indicate that partial loss of cochlear neurons in $\operatorname{trk} C^{\text {shc/shc }}$ mice did not qualitatively impair target innervation or hearing.

\section{Loss of sensory innervation of the aortic arch in trkB ${ }^{\text {shc/shc }}$ mutants}

We next asked if equivalent defects could be found in other cranial sensory neurons, subpopulations of which are also dependent on signaling through TrkB or TrkC receptors. We accordingly analyzed visceral target innervation by nodose-petrosal ganglion cells. Nodose-petrosal neurons are TrkB-dependent, yet heterogeneous with
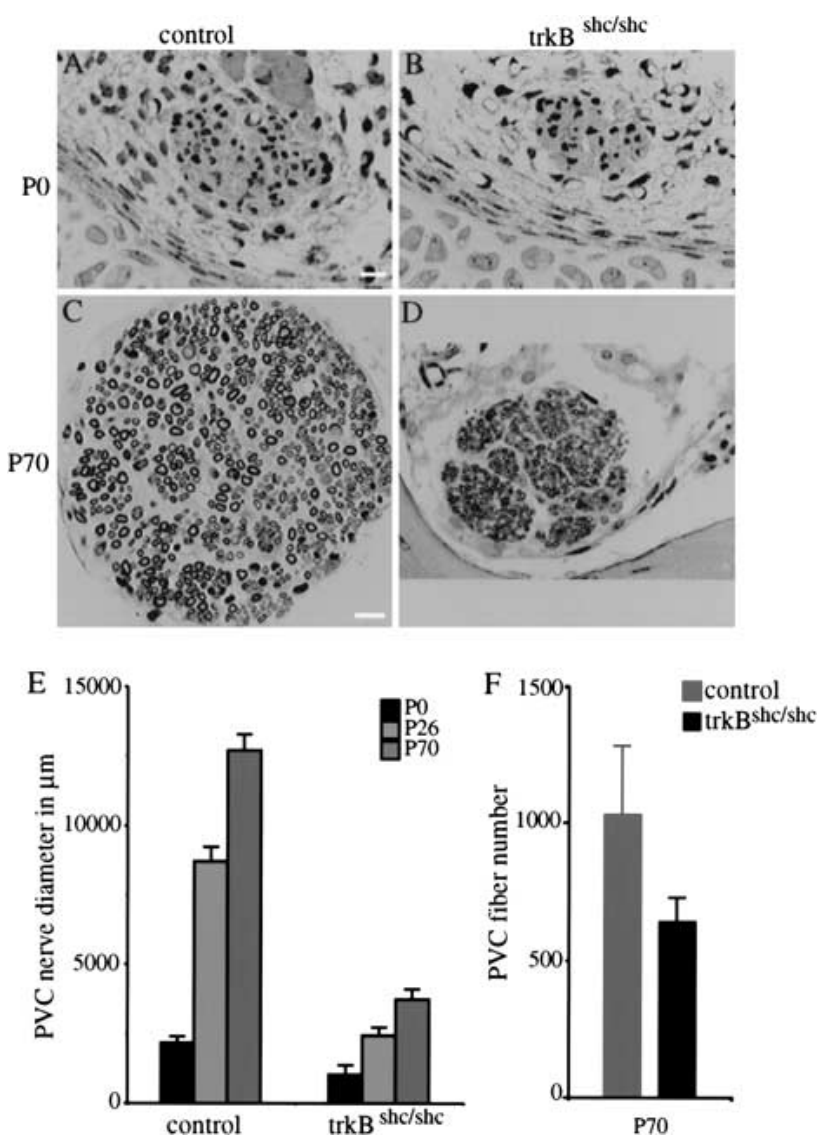

Figure 4. Severe reduction of vestibular peripheral nerve in trk $B^{\text {shc/shc }}$ mutants. $(A-D)$ Cross sections of the posterior vertical canal (PVC) nerve stained with osmium tetroxide of $\mathrm{P} 0(A, B)$ and $\mathrm{P} 70(C, D) \mathrm{trk} B^{\text {shc/shc }}$ mutants and control wild-type littermates. (E) Time course of PVC nerve growth in $\operatorname{trk} B^{\text {shc/shc }}$ mutants and control wild-type littermates. $(F)$ PVC nerve fiber quantification at P70. Scale bar, $10 \mu \mathrm{m}(A-D)$. 


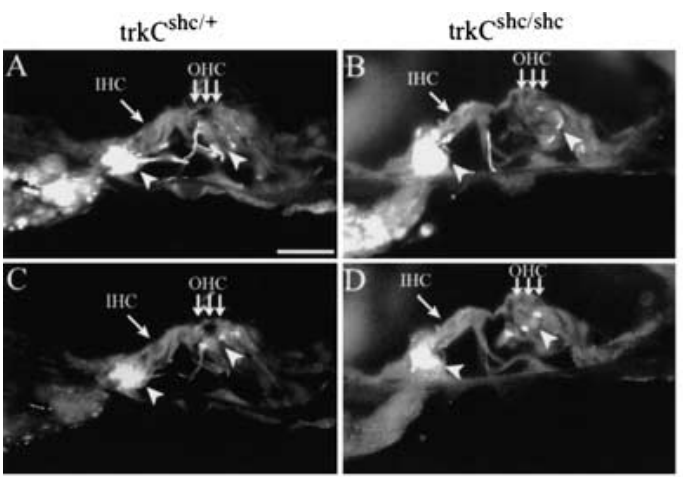

$\mathrm{K}$

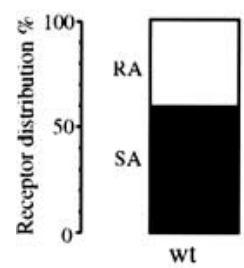

wt $n=41$
A fibers

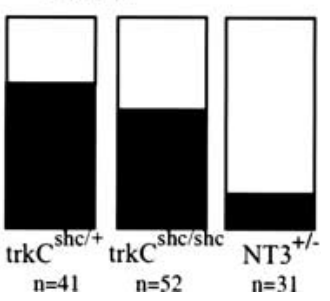

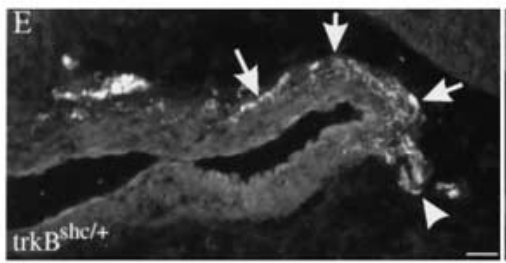
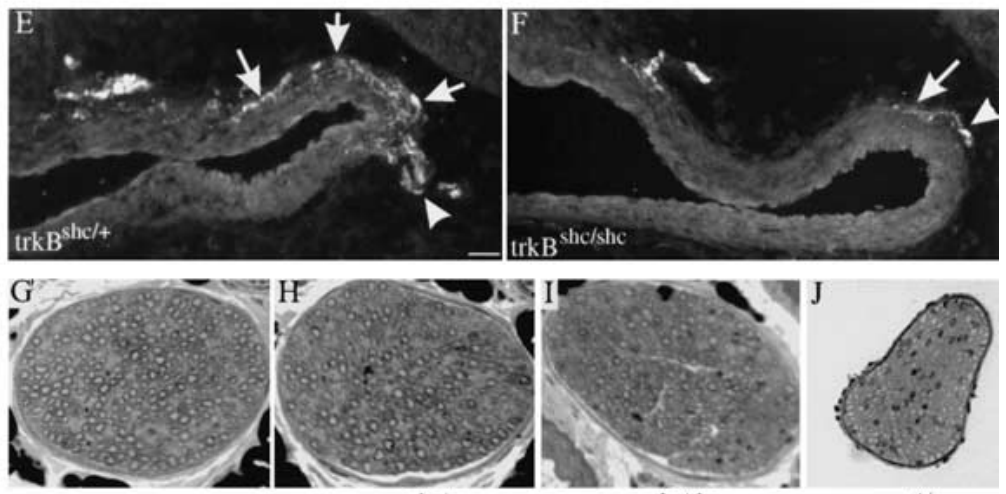

WT

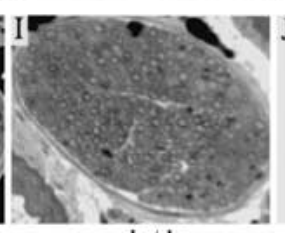

trkC $C^{\text {she/she }}$

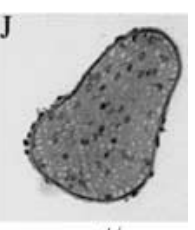

$\mathrm{NT}^{+/-}$

Figure 5. Innervation of cochlear sensory epithelia and functionality of trunk sensory neurons in $t r k C^{s h c / s h c}$ mutants. $(A-D)$ Cochlear sections through the organ of Corti of adult control trk $C^{s h c /+}$ animals and $t r k C^{s h c / s h c}$ mutants were labeled with either $(A, B)$ anti-NF200 antibody to visualize afferent innervations, or $(C, D)$ anti-synaptophysin antibody to reveal efferent innervations. Closed arrowheads point to fibers; arrows mark inner (IHC) and outer hair cells $(\mathrm{OHC}) .(A, B) \mathrm{trk}^{\mathrm{shc} / \mathrm{shc}}$ mice show a normal pattern of NF200-immunopositive afferent innervation opposite outer hair cells (OHCs) and along the length of their projection. $(D)$ Strong synaptophysin staining was noted opposite all three $\mathrm{OHC}$ rows indicating normal-sized efferent synapses. $(E, F)$ Representative photomicrographs of sagittal sections through the aortic arch of a control $t r k B^{s h c /+}$ mouse $(E)$ and $\operatorname{trk} B^{s h c / s h c}$ mutant mouse $(F)$. Staining with anti-PGP 9.5 reveals nerve fibers (similar results were obtained in a total of $n=3$ animals for all genotypes). Rostral is to the right. Arrows indicate baroreceptor fibers within the wall of the arch. Arrowheads point to the aortic depressor nerve. $(G-J)$ Representative plastic sections of the purely cutaneous saphenous nerve taken from wild-type $(C), \operatorname{trk} C^{\text {shcl+ }}(D)$, $\operatorname{trk} C^{\text {shc/shc }}(E)$, and $N T 3^{+/-}(F)$ mice. $(K)$ Physiological recordings made from large-diameter sensory fibers in the saphenous nerve indicate no loss of slowly adapting mechanoreceptors (SA) in $\mathrm{trk} C^{\mathrm{shc} / \mathrm{shc}}$ mutant mice. In contrast, a large depletion of SA fibers has been observed in NT3 heterozygous mice (data replotted for comparison from Airaksinen et al. 1996). Scale bars, $10 \mu \mathrm{m}(A-D), 20 \mu \mathrm{m}(E, F)$, and $50 \mu \mathrm{m}(G-J)$.

respect to their response to BDNF and NT4, and previous studies have shown that $\sim 50 \%$ of them die in BDNF or NT4 knockout mice (Erickson et al. 1996). Mutation of the Shc site in TrkB causes a partial loss of nodose-petrosal neurons that primarily involves the NT4-dependent subset (Minichiello et al. 1998; Fan et al. 2000). To determine whether target innervation of the surviving BDNF-dependent nodose neurons was affected in the trk $B^{\text {shc/shc }}$ mutants, we examined baroreceptor innervation of the aortic arch, which contributes to the neuronal circuits controlling blood pressure (Brady et al. 1999). Baroreceptor innervation in newborn $\operatorname{trk} B^{s h c /+}$ and $\operatorname{trk} B^{s h c / s h c}$ mice was analyzed in sagittal sections cut through the region of the aortic arch and stained with antibody against protein gene product (PGP) 9.5 to reveal nerve fibers. Heterozygous mice showed a normal pattern of baroreceptor innervation, consisting of a dense plexus of nerve fibers distributed circumferentially in the outer wall of the arch (Fig. 5E; data not shown). In contrast, sparse fibers were observed in the aortic arch of $\operatorname{trk} B^{s h c / s h c}$ mice, which only weakly ramified in the dorsal wall of the arch at the level of entry of the aortic depressor nerve (Fig. 5F). Moreover, the depressor nerve, which is the source of baroreceptor innervation to the arch, appeared much reduced in size in $\operatorname{trk} B^{s h c / s h c}$ mice compared with $\operatorname{trk} B^{\text {shc/+ }}$ animals (Fig. 5, cf. E and F). These data indicate that BDNF signaling through the TrkB Shc site is required for the maintenance of periph- eral baroreceptor fibers in the aortic arch, but, based on our previous studies (Minichiello et al. 1998; Fan et al. 2000), it is not required for the survival of their cell bodies in the nodose ganglion. This suggests that our observations in the vestibular organ may apply to other sensory systems.

\section{Intact D-hair mechanoreceptors in trkC $\mathrm{C}^{\text {shc/shc }}$ mice}

NT3 is required in the postnatal period to maintain the survival of slowly adapting mechanoreceptors (SAM), innervating Merkel cells, and D-hair mechanoreceptors (Airaksinen et al. 1996). Therefore, we asked whether the TrkC receptor Shc site was necessary for NT3 to maintain the survival of these subgroups of sensory neurons. We used an in vitro skin nerve preparation to record from single cutaneous sensory neurons in the saphenous nerve (Koltzenburg and Lewin 1997). For each genotype 3-7 mice were used, and between 60 and 92 single $A \beta$ fibers and A $\delta$-fibers were recorded. We found no selective loss of $A \beta$-fibers (conduction velocity $>10 \mathrm{~m} / \mathrm{sec}$ ) characterized as SAMs in $\operatorname{trk} C^{s h c /+}$ or $\operatorname{trk} C^{s h c / s h c}$ mice compared to wild-type mice (Fig. 5K). Thus, as in the wildtype mice, $\sim 60 \%$ of $\mathrm{A} \beta$-fibers in both $\operatorname{trk} \mathrm{C}^{\text {shc/+ }}$ and trk $C^{s h c / s h c}$ mice were found to be SAM, and the remaining receptors could be characterized as rapidly adapting mechanoreceptors (RAM). This was in contrast to mice heterozygous for an NT3 null mutation, where the pro- 
portion of SAM neurons among the A $\beta$-fibers falls to only $\sim 15 \%$ (Fig. 5K, data replotted from Airaksinen et al. 1996). In NT3-deficient mice, a loss of D-hair receptors that have $A \delta$-fiber conduction velocities between 1 and $10 \mathrm{~m} / \mathrm{sec}$ is also observed. However, in $\operatorname{trk} C^{\text {shc/shc }}$ mice, no loss of D-hair receptors was observed; the proportion of D-hair receptors recorded in wild-type, $\operatorname{trk} C^{\text {shc/+ }}$, and trkC $C^{s h c / s h c}$ mice was $42 \%(n=19), 41 \%(n=22)$, and $44 \%(n=41)$, respectively. The remaining receptors recorded with A $\delta$-fiber conduction velocities for each genotype could be characterized as nociceptors (Koltzenburg and Lewin 1997). To confirm these physiological findings, we also counted the number of myelinated axons remaining in the saphenous nerve in $\mathrm{trk} C^{\text {shc/sho }}$ mutants. Here we found that the number of myelinated axons present in $\operatorname{trk} C^{s h c /+}$ or $\operatorname{trk} C^{s h c / s h c}$ mice was not different $(470 \pm 11$ and $459 \pm 8$, respectively; $P=0.09 t$ test, $n=5$ nerves per genotype). This represents a small reduction $(12 \%)$ compared with counts of axons taken from wild-type mice ( $518 \pm 6 ; n=2$ nerves); however, the loss of axons in mice that are only heterozygous for the NT3 mutation leads to a much larger reduction in the axon number of $\sim 30 \%-35 \%$ (Fig. 5G-J). Likewise, the subpopulation of proprioceptive DRG neurons, the large class Ia afferents, was found to be only modestly reduced in $\operatorname{trk} C^{s h c / s h c}$ mutants, either by cell body size measurements or based on in situ hybridization using $\operatorname{trk} C$ as a probe (data not shown). In summary, our data suggest that the Shc site is differently required for maintenance of target innervation in TrkC-dependent versus TrkBdependent neurons.

\section{The TrkB Shc site is required for synapse formation in vestibular sensory epithelia}

Insufficient synapse formation may cause loss of target innervation. Therefore, we examined the innervation of vestibular sensory epithelia at the ultrastructural level, to determine if afferent and efferent fibers would form synapses on sensory epithelia. In adult (P70) or juvenile (P26) $t r k B^{s h c / s h c}$ mutant mice, no fibers or synapses were detected in the canal epithelia (data not shown). In the utricle or saccular epithelia, only small synaptic contacts or partial calyces, respectively, were identified (data not shown). We then investigated synapse formation at earlier stages, when target innervation is still largely normal. Whereas the control animals, indeed, formed partial calyces at P0 in the canal epithelia and utricle, the $\operatorname{trk} B^{s h c / s h c}$ mutants had no contacts in the canal sensory epithelia (Fig. 6A,B) and only small bouton-like synapses in the utricle (Fig. 6C,D). These data suggest an important role for the TrkB Shc site in promoting synapse formation in the vestibular epithelia. In contrast, normal synapse formation was observed in the cochlea sensory epithelia of $\operatorname{trk} C^{s h c / s h c}$ mutants and $\operatorname{trk} B^{\text {shc/shc }}$; $t r k C^{s h c / s h c}$ double-mutant mice from the remaining neurons in the cochlear ganglion. Outer hair cells in the basal turn of the cochlea of $\operatorname{trk} B^{\text {shc/shc }}$; trk $C^{\text {shc/shc }}$ double-mutant mice showed normal innerva-
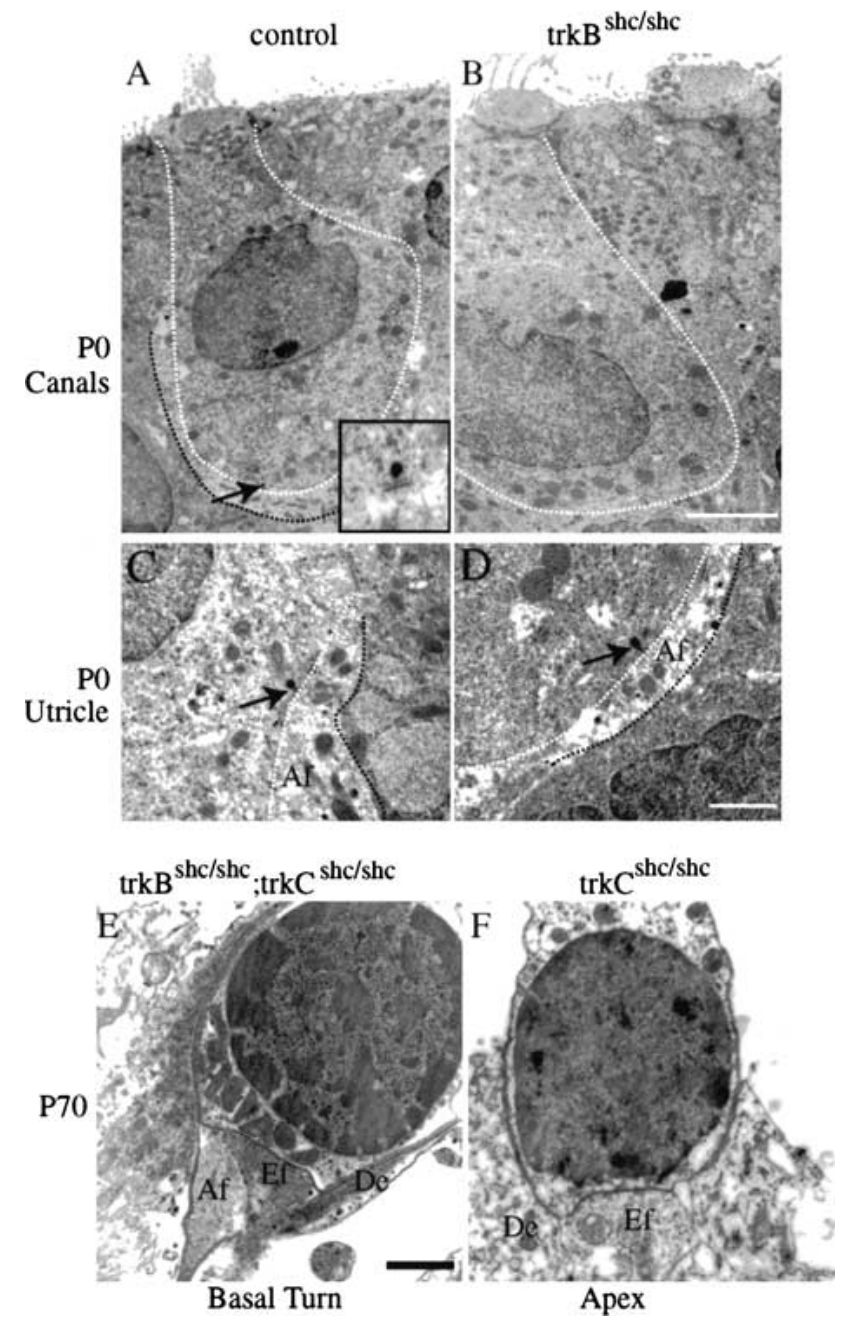

Figure 6. Lack of synaptic contacts in sensory epithelia of trkk $B^{s h c / s h c}$, but not $t r k C^{s h c / s h c}$ mutant mice. Representative electron micrographs (EM) showing synapses in P0 canals $(A, B)$ and utricle sensory epithelia $(C, D)$ of $\operatorname{trk} B^{\text {shc/shc }}$ mutant mice compared with controls. $(A)$ Control individual hair cell outlined by a white stippled line is surrounded by an afferent nerve terminal (black stippled line indicates the partial calyx of this fiber), which already at P0 is adjacent to a presynaptic bar (indicated by an arrow, see also inset in panel $A$ ). A small black dot and a synaptic cleft underneath characterize the presynaptic bar. In contrast, P0 trk $B^{\text {shc/shc }}$ mutants do not show any synaptic fiber near hair cells and no synaptic contact in the canal sensory epithelia $(B)$. In the utricle, afferent (Af) and occasionally efferent (Ef) contacts can be identified in both control $(C)$ and $\operatorname{trk} B^{\text {shc/shc }}$ mutant mice $(D)$ as early as P0. However, these contacts remain small in the $\operatorname{trk} B^{\text {shc/shc }}$ mutants and never form calyces. $(E, F)$ EM showing normal synapse formation in the cochlea sensory epithelia of $t r k C^{s h c / s h c}$ mutant mice and $\operatorname{trk} B^{\text {shc/shc }}$; trk $C^{\text {shc/shc }}$ double-mutant mice at P70. The basal turn of the $\operatorname{trk} B^{\text {shc/shc }}$; $\operatorname{trk} C^{\text {shc/shc }}$ double-mutant mice $(E)$ is used as a control and shows the normal pattern of afferent (Af) and efferent (Ef) termini at the base of the basal turn outer hair cell. Note also the presence of Deiter's cell processes (supporting cells, De) around the outer hair cell. The hair cell shows a nucleus with heterochromatin around the perimeter, and mitochondria may be found between the nucleus and synaptic contact region. $(F)$ In the apex $t r k C^{\text {shc/shc }}$ mutants retain efferents to the innermost row of outer hair cells. Scale bars, $5 \mu \mathrm{m}(A, B), 1 \mu \mathrm{m}(C-F)$. 
tion patterns and were used here as controls (Fig. 6E). Similarly, in the apex region of the mutant mice, remaining neurons made proper contacts (Fig. 6F). In summary, whereas surviving cochlear neurons in $\operatorname{trk} C^{s h c / s h c}$ mutants form synaptic contacts and maintain sensory epithelia innervation, surviving vestibular neurons in trk $B^{\text {shc/shc }}$ mutants fail to form synaptic contacts and subsequently suffer from degeneration of their peripheral fibers.

\section{Mutation of the conserved Shc-binding motif reduces TrkB, but not TrkC, autophosphorylation}

A possible explanation for the observed differences between TrkB and TrkC receptors is that they are capable of eliciting distinct signaling outputs despite their structural similarities. To gain insight into the mechanism responsible for the distinct signaling outputs, we have tested the requirement of the Shc site for full activation of the two receptors. Mutation of the Shc site impairs TrkB autophosphorylation (60\% reduction) in response to BDNF (Fig. 7B; Minichiello et al. 1998), but does not affect full activation of TrkC in response to NT3* (Fig. 7A). This suggests that the unphosphorylated juxtamembrane region of $\operatorname{TrkB}$, but not of TrkC, has an inhibitory effect on kinase activity. Possibly as a result of partial autoinhibition, we find that PLC $\gamma 1$ binding to the other conserved tyrosine in the $\mathrm{C}$-terminal region of Trk receptors is reduced in TrkB ${ }^{\text {shc }}$. As shown in Figure 7C, $\mathrm{PLC} \gamma 1$ is rapidly phosphorylated on tyrosine residues upon stimulation of either wild-type TrkC or TrkC $\mathrm{C}^{\text {shc }}$ mutant receptors. Immunoprecipitation of PLC $\gamma 1$ brings down TrkC ${ }^{\text {shc }}$ both at early $(1 \mathrm{~min})$ and late time points $(5 \mathrm{~min})$. In contrast, association of PLC $\gamma 1$ and TrkB ${ }^{\text {shc }}$ is weak, resulting in loss of coimmunoprecipitation after 5 min of BDNF stimulation (Fig. 7D, middle panel). This effect is the result of mutation of the Shc site, because wild-type TrkB binds PLC $\gamma 1$ more robustly and is still coimmunoprecipitated after $20 \mathrm{~min}$. Although we do not have evidence that PLC $\gamma$ signaling per se is affected in trk $B^{s h c / s h c}$ mutants, it is possible that prolonged association of PLC $\gamma$ with Trk receptors stabilizes a signaling complex including other signaling molecules, which promote target innervation.

\section{Discussion \\ Similarities and differences in signaling output of $\operatorname{Trk} B$ and $\operatorname{Trk} C$ receptors}

In vitro cell systems had previously suggested that two different neurotrophins, BDNF and NT3, presumably acting through TrkB and TrkC receptors, respectively, have very different effects on the same target neuron (Shieh and Ghosh 1997, and references therein). Moreover, previous work on $\operatorname{TrkB}$ and $\operatorname{TrkC}$ signaling in growth cone turning by Poo and colleagues suggests differences in Trk signaling (Song and Poo 1999). So far, however, biochemical differences in Trk-mediated signaling pathways, which could explain these effects, have
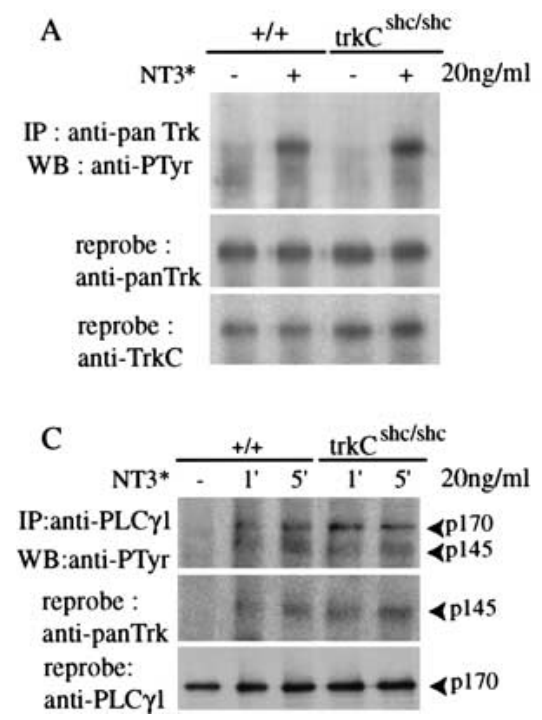
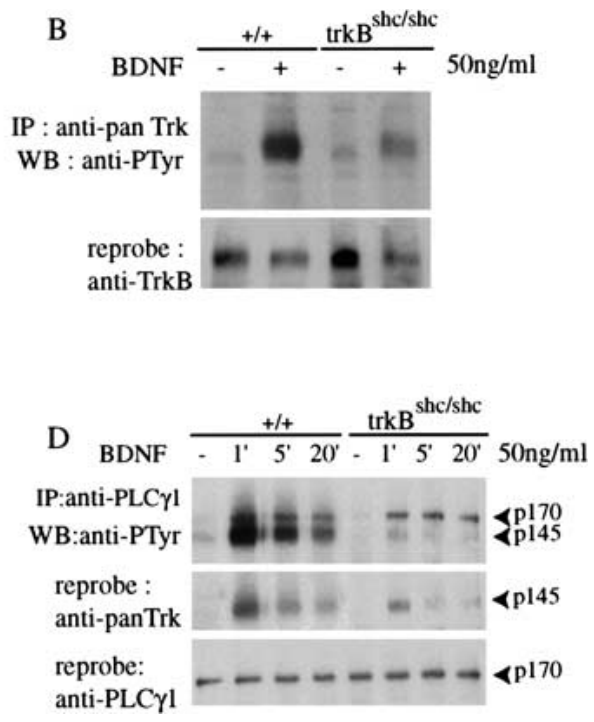

Figure 7. Control of TrkB autophosphorylation by the Shc adaptor binding site. (A) Autophosphorylation of TrkC in cortical neurons. Cortical neurons derived from wild-type animals and $t r k C^{s h c / s h c}$ mutants were stimulated with NT3* for 5 min. Cell lysates were immunoprecipitated with anti-panTrk antibody followed by immunoblotting with anti-PTyr antibody. The blot was reprobed with antipanTrk antibody and with anti-TrkC antibody to visualize the levels of TrkC protein. (B) Autophosphorylation of TrkB in cortical neurons. Cortical neurons derived from wild-type animals and $\operatorname{trk} B^{\text {shc/shc }}$ mutants were stimulated with BDNF for 5 min. Cell lysates were immunoprecipitated with anti-panTrk antibody followed by immunoblotting with anti-PTyr antibody. The blot was than reprobed with anti-TrkB to visualize protein levels. $(C)$

PLC $\gamma 1$ stably binds mutant TrkC $C^{\text {shc }}$ receptors. Cortical neurons derived from wild-type animals and $t r k C^{s h c / s h c}$ mutants were treated with NT3* for different length of times. Cell lysates were immunoprecipitated with anti-PLC $\gamma 1$ antibody and immunoblotted with anti-PTyr antibody. Normal tyrosine phosphorylation was observed for PLC $\gamma 1$ proteins after 1 or 5 min stimulation in wild-type animals and $t r k C^{s h c / s h c}$ mutants. The blot was reprobed with anti-panTrk and anti-PLC $\gamma 1$ antibodies. $(D)$ Impaired association of PLC $\gamma 1$ with mutant TrkB ${ }^{\text {shc }}$ receptors. Cortical neurons derived from wild-type animals and $\operatorname{trk} B^{\text {shc/shc }}$ mutants were treated with BDNF for different length of times. Lysates were immunoprecipitated with anti-PLC $\gamma 1$ antibody and immunoblotted with anti-PTyr antibody. Normal tyrosine phosphorylation of PLC $\gamma 1$ was observed in wild-type and mutant cells. Coimmunoprecipitation of PLC $\gamma 1$ and TrkB was impaired in cells expressing $t r k B^{s h c / s h c}$, compared with cells expressing wild-type TrkB. The blot was reprobed with anti-panTrk and anti-PLC $\gamma 1$ antibody. 
not been reported. Furthermore, it is unclear whether similar differences in Trk signaling are present and, more importantly, are required for their biological functions in vivo. To determine whether two Trk receptors use similar or different docking sites for intracellular effectors in vivo, we mutated the Shc sites on both TrkB and TrkC receptors (Minichiello et al. 1998). We found distinct signaling requirements for the Shc site in sensory neurons. Whereas the Shc site in TrkB and TrkC receptors plays a minor role in survival, it is critically required downstream of TrkB for the maintenance of target innervation. In contrast, TrkC receptors appear to use Shc siteindependent mechanisms to regulate target innervation and neuronal function.

What is responsible for the different effects of the Shc site in Trk $B$ and TrkC receptors?

Receptor signaling for target innervation had been impossible to study genetically in the null mutants, because the dependent neuron populations disappeared in the absence of Trk receptors. The generation of Shc site mutants allows us to separate survival from target innervation. Because the cell populations that depend on TrkB versus TrkC signaling are different /vestibular vs. cochlear neurons), one might argue that different cellular contexts like changes in neurotrophic factor dependency may determine the different biological responses. In the case of cochlear neurons, could a switch from NT3 to BDNF account for our observations? We think this is less likely. For example, there is (as described in Fig. 6E) no additional effect of crossing $\operatorname{trk} B^{\text {shc/shc }}$ mice with trk $C^{\text {shc/shc }}$ mice with respect to axon maintenance in cochlear neurons. Moreover, NT3, which is continuously expressed in the saccule and utricle, cannot rescue the axon maintenance defect in the $\operatorname{trk} B^{s h c / s h c}$ mice. Could a third factor, such as GDNF, be involved in maintaining target innervation in $\operatorname{trk} C^{s h c / s h c}$ mice? We cannot formally exclude it; although GDNF has been amply shown to be a neuronal survival factor (Buj-Bello et al. 1995), no role for it has been described so far in maintaining target innervation. Moreover, two different TrkB-dependent neurons, vestibular and nodose neurons, show similar reductions in target innervation, and three populations of TrkC-dependent neurons, cochlear, DRG proprioceptive, and D-hair mechanoreceptive neurons, all maintain target innervation and functionality. Taken together, this rather suggests that the observed differences between TrkB and TrkC reflect different signaling properties of the two related receptors. This is not without precedent. Recently, Klinghoffer et al. (2001) reported on a study in which the intracellular domains of the highly related $\alpha$ and $\beta$ isoforms of the platelet-derived growth factor (PDGF) receptor were exchanged using knock-in mice. Mice carrying the $\beta \alpha$ hybrid receptors were viable, but suffered from moderate cardiac hypertrophy, suggesting that PDGF $\beta$ receptors use additional/ distinct intracellular mechanisms compared with the PDGF $\alpha$ receptors (Klinghoffer et al. 2001).
The Shc site negatively regulates autophosphorylation in TrkB but not in TrkC

The signals mediating target innervation and maintenance by the TrkB receptors include the PI3K/AKT and the Ras/MAPKs pathways, both of which converge signaling on a number of cytoskeletal proteins that could mediate axonal growth and elongation (Atwal et al. 2000). These two pathways are similarly affected by the Shc site mutation in both TrkB and TrkC receptors. Remarkably, target innervation is maintained in the remaining TrkC-dependent neurons. These data suggest that TrkC is able to use alternative mechanisms to regulate proper target innervation, and to maintain functional axon tracts. Atwal et al. (2000) have shown that the Shc site in TrkB signals axon growth in sympathetic neurons via Mek and PI3K. Contrary to our in vivo results, they found in their in vitro system that the same site also regulates survival. The difference may be due to the fact that Atwal et al. studied sympathetic neurons, whereas our study focused on sensory neurons. Alternatively, in vivo, neurons may have access to additional extracellular matrix molecules, which could enhance the signals mediated by the mutant $\operatorname{Trk} \mathrm{B}^{\text {shc }}$ receptor. Therefore, the Shc site mutation may be partially compensated for, and the resulting cell survival deficit may be milder compared with an in vitro situation. Previous reports had shown that in dissociated granule cell cultures, BDNF enhanced neurite outgrowth, whereas NT3 had no effect on neurite outgrowth but enhanced fasciculation (Segal et al. 1995). Although there is at present no in vivo correlate for cerebellar functions of BDNF and NT3, together these results suggest that although Trk receptors have highly conserved intracellular domains, regulation of signals activated by these two proteins may significantly diverge. To gain more insight into the mechanism that would be responsible for distinct signaling outputs of TrkB versus TrkC, we have tested the requirement of the She site for full activation of the two receptors. Mutation of the Shc site reduces TrkB autophosphorylation in response to BDNF, but does not affect full activation of TrkC in response to NT3*. Our data suggest that in the juxtamembrane region of TrkB and TrkC, phosphorylation of the tyrosine residue in the consensus sequence NPQY is required for full activation of TrkB, but not for TrkC. There are examples of other receptor tyrosine kinases including the $\beta$-PDGF receptor, whose full activation requires phosphorylation of two tyrosines (579 and 581) in the juxtamembrane region (Baxter et al. 1998). Moreover, Wybenga-Groot et al. (2001) present structural data showing that the unphosphorylated juxtamembrane region of EphB2 autoinhibits EphB2 kinase activity. Our data on the mutant Trk receptor suggest that similar autoinhibition may occur in TrkB but not in TrkC. This negative autoregulation may result in a decrease in TrkB signaling below a critical threshold required for maintenance of target innervation. To extend these studies and further elucidate the mechanisms that lead to differential regulation of TrkB and TrkC, it would be necessary to gain insight into their 
structural features, as recently described for the EphB2 receptor (Wybenga-Groot et al. 2001).

\section{Materials and methods}

\section{Targeting vector and generation of chimeric mice}

The genomic phage used to construct the targeting vector (pAP38) contained a 15.8-kb insert with a single exon that encodes juxtamembrane residues of TrkC, including the NPQY ${ }^{516}$ adaptor binding site. A single point mutation $(\mathrm{A} \rightarrow \mathrm{T})$ was introduced by PCR-aided mutagenesis. This gives rise to a tyrosine 516 to phenylalanine substitution and disrupts an ScaI site, which was used for the Southern analysis of targeted ES clones. A HindIII site was engineered 3' of the loxP-Neo cassette for further Southern analysis. Electroporation of E14 ES cells, selection with G418, and blastocyst injections were carried out essentially as described (Minichiello et al. 1998). The Neo cassette was removed using Cre-mediated excision in vivo (Schwenk et al. 1995). Mice were bred into a mixed 129xC57) B16 background.

\section{NIH-3T3 and neuronal cultures}

NIH-3T3 fibroblasts stably expressing TrkB or TrkC were treated as in Lamballe et al. (1993) and Minichiello et al. (1998) and stimulated with BDNF, NT3 (Regeneron Pharmaceuticals, Inc.), or mutant NT3. The mutant NT3 (31/33 NT3) was prepared from baculovirus-infected insect cells as previously described (Rydén and Ibañez 1996).

Neuronal cultures were established from embryonic day 15.5 (E15.5) mouse cerebral cortices derived from intercrosses of wild-type, $\operatorname{trk} C^{s h c / s h c}$, or $\operatorname{trk} B^{s h c / s h c}$ mice as previously described (Minichiello et al. 1998).

\section{Biochemistry}

NIH-3T3 fibroblasts or cortical neuron cultures were stimulated for different lengths of time with $20 \mathrm{ng} / \mathrm{mL} \mathrm{NT3}{ }^{\star}$, 50 $\mathrm{ng} / \mathrm{mL}$ normal NT3, or $50 \mathrm{ng} / \mathrm{mL}$ BDNF. After stimulation the cells were harvested and treated as in Minichiello et al. (1998). Specific antibodies used in this study include: anti-panTrk polyclonal antibody (41-4, Martin-Zanca et al. 1989; C-14, Santa Cruz), anti-TrkB antiserum raised against the kinase domain of TrkB (113-5), anti-phosphotyrosine 4G10 and anti-PLC $\gamma 1$ monoclonal antibody (UBI), anti-Shc polyclonal antibody (Transduction Laboratories), anti-FRS2 polyclonal antibody (Santa Cruz), anti-p44/42 MAPK monoclonal antibody (Biolabs), anti-pAKT and anti-AKT antibodies (Biolabs), monoclonal anti$\alpha$-tubulin (Sigma), and anti-TrkC antibody 656 (Tsoulfas et al. 1993).

\section{Histology, neuron counts, and morphometric analysis}

Histological analysis was carried out essentially as described (Minichiello et al. 1998). Briefly, mouse heads (P7-P70) were decalcified in $5 \%$ formic acid in phosphate-buffered saline, embedded in paraffin, serial-sectioned at $8 \mu \mathrm{m}$, and stained with $0.1 \%$ cresyl violet. For counting, vestibular and cochlear neurons were identified by virtue of the Nissl substance; neurons were counted every 5 sections (40 $\mu \mathrm{m}$ apart). The Abercrombie method (Abercrombie 1946) was used to correct values for split nuclei. The morphometric analysis of the neurons and measurement of the area of different profiles per genotype were carried out using the NIH-Image Program.

\section{Immunohistochemistry}

For the inner ear immunohistochemistry, cochlear and vestibular organs from controls and mutant mice of different stages were isolated and dissected as described in Knipper et al. (1997). The specific antibodies used were anti-NF200 (polyclonal, N4142, Sigma) and anti-synaptophysin (monoclonal, clone SVP38 , Sigma). For the analysis of baroreceptor innervations, tissue preparation and section immunostaining with PGP 9.5 antibody (Accurate), were performed as described (Erickson et al. 1996).

\section{DiI tracing}

To reveal the ear innervation pattern, we have used the lypophilic tracer DiI in P0 and P8 mice of different genotypes fixed by transcardiac perfusion with $4 \%$ PFA. Briefly, DiI-soaked filter strips were inserted into either rhombomere 4 (for efferent and vestibular afferent fiber labeling) or into the ascending inner ear afferents at the medullary/pontine junction to label all afferents to the ear (Fritzsch and Nichols 1993). Ears were dissected, mounted whole, and viewed with an epifluorescent microscope.

\section{Transmission Electron Microscopy and nerve diameter}

Controls and mutant mice at different stages (P0, P8, P26, and P70) were fixed by transcardiac perfusion with $4 \%$ PFA and $0.5 \%$ glutaraldehyde in $0.1 \mathrm{M}$ phosphate buffer $(\mathrm{pH} 7.4)$, and kept in fixative for at least $4 \mathrm{~d}$. Ears were dissected, osmicated for $1 \mathrm{~h}$, decalcified using EDTA, and embedded in epoxy resin. Thick $(2-\mu \mathrm{m})$ and ultrathin $(0.5-\mu \mathrm{m})$ sections were taken for light and electron microscopic examinations. The diameter of the nerve to the posterior vertical canal (PVC) was measured using ImagePro software. The number of nerve fibers in the posterior vertical canal of P0, P26, and P70 animals was determined by counting fibers on photographs taken at random throughout the nerve; the total number of fibers was then calculated using the measured area of the nerves. At least three sections at different levels of one canal, the saccule, and the utricle were examined per animal. We also investigated the presence of nerve fibers and synapses in the vestibular sensory epithelia as well as the type of hair cells using criteria recently described in detail (Rüsch et al. 1998; Lysakowski et al. 1999).

\section{Nerve histology and electrophysiology}

The saphenous nerve histology was carried out essentially as described (Airaksinen et al. 1996). For the electrophysiological analysis, an in vitro skin/nerve preparation was used to record from functionally single primary afferents in micro-dissected teased filaments of the saphenous nerve as described (Koltzenburg and Lewin 1997).

\section{Acknowledgments}

We thank EMBL transgenic service, EMBL animal resource department, and J. Klewer for excellent technical support, and C. Martinez-Salgado for help in data collection work. We also thank P. Tsoulfas for the 656 anti-TrkC antibody, F.C. Ibañez, for the mutant NT3, L.Tessarollo for the trkC probe, and C. Nerlov for critical reading of the manuscript. Support for this study was provided in part by grants from the European Union and the Deutsche Forschungsgemeinschaft (SFB 488) to R.K., the NASA (NAG 2-1353) to B.F., and the DFG (SPP 1025) to G.L.

The publication costs of this article were defrayed in part by payment of page charges. This article must therefore be hereby 
marked "advertisement" in accordance with 18 USC section 1734 solely to indicate this fact.

\section{References}

Abercrombie, M. 1946. Estimation of nuclear populations from microtome sections. Anat. Rec. 94: 239-242.

Airaksinen, M., Koltzenburg, M., Lewin, G., Masu, Y., Helbig, C., Eckhard, W., Brem, G., Toyka, K., Thoenen, H., and Meyer, M. 1996. Specific subtypes of cutaneous mechanoreceptors require neurotrophin-3 following peripheral target innervation. Neuron 16: 287-295.

Alcantara, S., Frisen, J., del Rio, J.A., Soriano, E., Barbacid, M., and Silos-Santiago, I. 1997. TrkB signaling is required for postnatal survival of CNS neurons and protects hippocampal and motor neurons from axotomy-induced cell death. J. Neurosci. 17: 3623-3633.

Atwal, J.K., Massie, B., Miller, F.D., and Kaplan, D.R. 2000. The TrkB-Shc site signals neuronal survival and local axon growth via MEK and PI3-Kinase. Neuron 27: 265-277.

Baxter, R.M., Secrist, J.P., Vaillancourt, R.R., and Kazlauskas, A. 1998. Full activation of the platelet-derived growth factor B-receptor kinase involves multiple events. I. Biol. Chem. 273: $17050-17055$.

Berglund, A.M. and Ryugo, D.K. 1986. A monoclonal antibody labels type II neurons of the spiral ganglion. Brain Res. 383: 327-332.

Bibel, M. and Barde, Y.A. 2000. Neurotrophins: Key regulators of cell fate and cell shape in the vertebrate nervous system. Genes \& Dev. 14: 2919-2937.

Brady, R., Zaidi, S., Mayer, C., and Katz, D. 1999. BDNF is a target-derived survival factor for arterial baroreceptor and chemoafferent primary sensory neurons. I. Neurosci. 19: 2131-2142.

Buj-Bello, A., Buchman, L., Horton, A., Rosenthal, A., and Davies, A.M. 1995. GDNF is an age-specific survival factor for sensory and autonomic neurons. Neuron 15: 821-828.

Conover, J., Erickson, J., Katz, D., Bianchi, L., Poueymirou, W.T., McClain, J., Pan, L., Helgren, M., Ip, N., Boland, P., et al. 1995. Neuronal deficits, not involving motor neurons, in mice lacking BDNF and/or NT4. Nature 375: 235-238.

Davies, A.M., Minichiello, L., and Klein, R. 1995. Developmental changes in NT3 signalling via TrkA and TrkB in embryonic neurons. EMBO J. 14: 4482-4489.

Erickson, J.T., Conover, C.J., Borday, V., Champagnat, J., Barbacid, M., Yancoupoulos, G., and Katz, D.M. 1996. Mice lacking brain-derived-neurotrophic factors exhibit visceral sensory neuron losses distinct from mice lacking NT4 and display a severe developmental deficit in control of breathing. J. Neurosci. 16: 5361-5371.

Ernfors, P., Lee, K., Kucera, J., and Jaenisch, R. 1994. Lack of neurotrophin-3 leads to deficiencies in the peripheral nervous system and loss of limb proprioceptive afferents. Cell 77: 503-512.

Fan, G., Egles, C., Sun, Y., Minichiello, L., Renger, J.J., Klein, R., Liu, G., and Jaenisch, R. 2000. Knocking the NT4 gene into the BDNF locus rescues BDNF deficient mice and reveals distinct NT4 and BDNF activities. Nat. Neurosci. 3: 350357.

Fariñas, I., Jones, K.R., Tessarollo, L., Vigers, A.J., Huang, E., Kirstein, M., deCaprona, M.D., Coppolas, V., Backus, C., Reichardt, L.F., et al. 2001. Spatial shaping of cochlear innervation by temporally-regulated neurotrophin expression. I. Neurosci. 21: 6170-6180.

Fritzsch, B. and Nichols, D.H. 1993. DiI reveals a prenatal ar- rival of efferents at the differentiating otocyst of mice. Hearing Res. 65: 51-60.

Fritzsch, B., Silos-Santiago, I., Bianchi, L., and Fariñas, I. 1997. The role of neurotrophic factors in regulating the development of inner ear innervation. Trends Neurosci. 20: 159164.

- 2000. Effects of neurotrophin and neurotrophin receptor disruption on the afferent inner ear innervation. Semin. Cell. Dev. Biol. 8: 277-284.

Kaplan, D.R. and Miller, F.D. 1997. Signal transduction by the neurotrophin receptors. Curr. Opin. Cell Biol. 9: 213-221.

- 2000. Neurotrophin signal transduction in the nervous system. Curr. Opin. Neurobiol. 10: 381-391.

Klein, R., Silos-Santiago, I., Smeyne, R.J., Lira, S.A., Brambilla, R., Bryant, S., Zhang, L., Snider, W.D., and Barbacid, M. 1994. Disruption of the neurotrophin-3 receptor gene trkC eliminates la muscle afferents and results in abnormal movements. Nature 368: 249-251.

Klinghoffer, R.A., Mueting-Nelsen, P.F., Faerman, A., Shani, M., and Soriano, P. 2001. The two PDGF receptors maintain conserved signaling in vivo despite divergent embryological functions. Mol. Cell 7: 343-354.

Knipper, M., Kopschall, I., Rohbock, K., Kopke, A.K., Bonk, I., Zimmermann, U., and Zenner, H. 1997. Transient expression of NMDA receptors during rearrangement of AMPAreceptor-expressing fibers in the developing inner ear. Cell Tissue Res. 287: 23-41.

Koltzenburg, M. and Lewin, G. 1997. Receptive properties of embryonic chick sensory neurons innervating skin. J. Neurophysiol. 78: 2560-2568.

Korte, M., Carroll, P., Wolf, E., Brem, G., Thoenen, H., and Bonhoeffer, T. 1995. Hippocampal long-term potentiation is impaired in mice lacking brain-derived neurotrophic factor. Proc. Natl. Acad. Sci. 92: 8856-8860.

Lamballe, F., Tapley, P., and Barbacid, M. 1993. trkC encodes multiple neurotrophin-3 receptors with distinct biological properties and substrate specificities. EMBO J. 12: 30833094.

Lysakowski, A., Alonto, A., and Jacobson, L. 1999. Peripherin immunoreactivity labels small diameter vestibular 'bouton' afferents in rodents. Hearing Res. 133: 149-154.

Martin-Zanca, D., Oskam, R., Miltra, G., Copeland, T., and Barbacid, M. 1989. Molecular and biochemical characterization of the human trk proto-oncogene. Mol. Cell. Biol. 9: 24-33.

McAllister, A., Katz, L., and Lo, D.C. 1999. Neurotrophins and synaptic plasticity. Annu. Rev. Neurosci. 22: 295-318.

Meakin, S.O., MacDonald, J.I., Gryz, E.A., Kubu, C.J., and Verdi, J.M. 1999. The signalling adapter FRS-2 competes with Shc for binding to the nerve growth factor receptor TrkA: A model for discriminating proliferation and differentiation. $J$. Biol. Chem. 274: 9861-9870.

Minichiello, L. and Klein, R. 1996. TrkB and TrkC neurotrophin receptors cooperate in promoting survival of hippocampal and cerebellar granule neurons. Genes \& Dev. 10: 28492858.

Minichiello, L., Casagranda, F., Tatche, R.S., Stucky, C.L., Postigo, A., Lewin, G.R., Davies, A.M., and Klein, R. 1998. Point mutation in trkB causes loss of NT4-dependent neurons without major effects on diverse BDNF responses. Neuron 21: 335-345.

Minichiello, L., Korte, M., Wolfer, D., Kuhn, R., Unsicker, K., Cestari, V., Rossi-Arnaud, C., Lipp, H.P., Bonhoeffer, T., and Klein, R. 1999. Essential role for TrkB receptors in hippocampus-mediated learning. Neuron 24: 401-414.

Mou, K., Hunsberger, C., Cleary, J., and Davis, R. 1997. Synergistic effects of BDNF and NT-3 on postnatal spiral ganglion 
neurons. J. Comp. Neurol. 386: 529-539.

Patterson, S., Abel, T., Deuel, T., Martin, K., Rose, J., and Kandel, E. 1996. Recombinant BDNF rescues deficits in basal synaptic transmission and hippocampal LTP in BDNF knockout mice. Neuron 16: 1137-1145.

Rüsch, A., Erway, L., Oliver, D., Vennstrom, B., and Forrest, D. 1998. Thyroid hormone receptor $\beta$-dependent expression of a potassium conductance in inner hair cells at the onset of hearing. Proc. Nat1. Acad. Sci. 95: 15758-15762.

Rydén, M. and Ibañez, F.C. 1996. Binding of neurotrophins-3 to p $75^{\text {LNGFR }}$, TrkA, and TrkB mediated by a single functional epitope distinct from that recognized by TrkC*. I. Biol. Sci. 271: 5623-5627.

Schwenk, F., Baron, U., and Rajewsky, K. 1995. A cre-transgenic mouse strain for the ubiquitous deletion of loxP-flanked gene segments including deletion in germ cells. Nucleic Acids Res. 23: 5080-5081.

Segal, R., Pomeroy, S., and Stiles, C. 1995. Axonal growth and fasciculation linked to differential expression of BDNF and NT3 receptors in developing cerebellar granule cells. I. Neurosci. 15: 4970-4981.

Shieh, P. and Ghosh, A. 1997. Neurotrophins: New roles for a seasoned cast. Curr. Biol. 7: R627-R630.

Song, H.-J. and Poo, M.-M. 1999. Signal transduction underlying growth cone guidance by diffusible factors. Curr. Opin. Cell Biol. 9: 355-363.

Spoendlin, H. 1988. Neural anatomy of the inner ear. In Physiology of the ear (eds. A. Jahn and J. Santos-Sachi), pp. 201219. Raven Press, New York, NY.

Tsoulfas, P., Soppet, D., Escandon, E., Tessarollo, L., MendozaRamirez, J.L., Rosenthal, A., Nikolics, K., and Parada, L.F. 1993. The rat trkC locus encodes multiple neurogenic receptors that exhibit differential response to neurotrophin-3 in PC12 cells. Neuron 10: 975-990.

Wiechers, B., Gestwa, G., Mack, A., Carrol, P., Zenner, H.P., and Knipper, M. 1999. A changing pattern of brain-derived-neurotrophinic factor expression correlates with rearrangement of fibres during cochlear development of rats and mice. $I$. Neurosci. 19: 3033-3042.

Wybenga-Groot, L., Baskin, B., Ong, S., Tong, J., Pawson, T., and Sicheri, F. 2001. Structural basis for autoinhibition of the EphB2 receptor tyrosine kinase by the unphosphorylated juxtamembrane region. Cell 106: 745-757.

Xu, B., Gottschalk, W., Chow, A., Wilson, R., Schnell, E., Zang, K., Wang, D., Nicoll, R., Lu, B., and Reichardt, L. 2000. The role of brain-derived neurotrophic factor receptors in the mature hippocampus: Modulation of long-term potentiation through a presynaptic mechanism involving TrkB. J. Neurosci. 20: 6888-6897. 


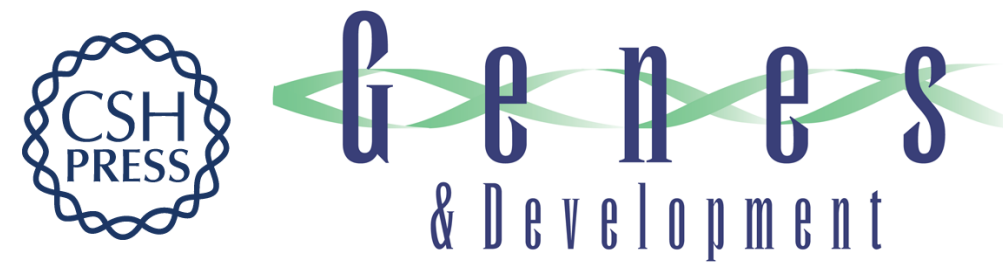

\section{Distinct requirements for TrkB and TrkC signaling in target innervation by sensory neurons}

Antonio Postigo, Anna Maria Calella, Bernd Fritzsch, et al.

Genes Dev. 2002, 16:

Access the most recent version at doi:10.1101/gad.217902

$\begin{array}{ll}\text { References } & \text { This article cites } 45 \text { articles, } 14 \text { of which can be accessed free at: } \\ \text { http://genesdev.cshlp.org/content/16/5/633.full.html\#ref-list-1 }\end{array}$

License

Email Alerting Receive free email alerts when new articles cite this article - sign up in the box at the top Service right corner of the article or click here.

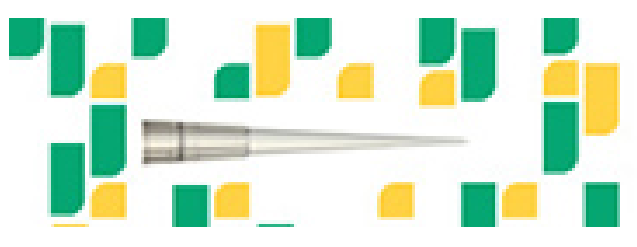

Focused on your science. 